\title{
PENGARUH VARIASI KONSENTRASI JAGUNG TERHADAP KUALITAS NATA DE CORN
}

\author{
Uswatun Hasanah ${ }^{1}$, Edi M. Jayadi ${ }^{2}$, Sulistiyana ${ }^{1}$ \\ ${ }^{1}$ Tadris Kimia, FTK UIN Mataram, Mataram. Email: \\ sulistchemist@uinmataram.ac.id \\ ${ }^{2}$ Tadris IPA Biologi, FTK UIN Mataram, Mataram
}

\section{ABSTRAK}

Nata adalah produk kaya serat yang dibuat dari berbagai media dengan persyaratan cukup sumber karbon, nitrogen, $\mathrm{pH}$ dan suhu. Jagung kaya akan vitamin A, B, dan E, Thiamin, Niacin, Pantothenic Acid, dan folat. Vitamin dan Niacin mendorong pertumbuhan sel. Panthothenic Acid penting untuk lipid, protein, dan metabolisme karbohidrat dalam tubuh. Penelitian ini bertujuan untuk mengetahui pengaruh variasi konsentrasi jagung terhadap kualitas nata de corn yaitu; rendemen, ketebalan, dan kadar air. Penelitian ini menggunakan penelitian eksperimen dengan pendekatan kuantitatif. fermentasi dilakukan pada suhu lingkungan selama 13 hari dengan variasi konsentrasi $0 \%$, 10\%, 20\% dan 30\%. Penelitian menggunakan pengulangan sebanyak 6 kali. Pada penelitian ini konsentrasi jagung berpengaruh nyata terhadap ketebalan dan kadar air tetapi tidak berpengaruh nyata pada rendemen nata de corn. Konsentrasi optimum pada analisis kualitas nata de corn ini adalah $20 \%$ dengan nilai rendemen $86,37 \%$, ketebalan $0,573 \mathrm{~cm}$ dan kadar air $84,466 \%$.

KATA KUNCI: Nata De Corn, Acetobacter xylinum, Jagung, Fermentasi

\section{PENDAHULUAN}

Nata adalah bahan menyerupai gel (agar-agar) yang terapung pada medium mengandung gula dan asam hasil bentukan mikroorganisme Acetobacter xylinum. Selain itu nata merupakan polikel atau polisakarida ekstraseluler 
(Majesty, dkk., 2015). Pembuatan nata awalnya hanya berkembang di Negara Filipina pada tahun 1960-an. Masyarakat di Negara Filipina terinspirasi dari masalah limbah air kelapa yang menimbulkan pencemaran air dan tanah. Pasalnya, negara ini merupakan salah satu negara penghasil kelapa terbesar di dunia untuk diolah menjadi kopra. Saat proses pembuatan kopra, air kelapa merupakan limbahnya. Limbah tersebut jika difermentasi oleh bakteri Acetobacter xylinum akan menjadi gelatin berwarna putih agak bening dan bertekstur agak kenyal (kaya serat) yang biasa disebut dengan nata de coco (Warisno, 2009).

Produk makanan nata bukan merupakan sesuatu yang asing lagi di kalangan masyarakat. Nata merupakan makanan pencuci mulut (desert) yang mengandung serat selulosa kadar tinggi yang bermanfaat bagi kesehatan dalam membantu memperlancar penyerapan makanan dalam tubuh dan membantu penderita diabetes yang diet gula. Oleh karena itu produk ini dipakai sebagai sumber makanan berkalori rendah untuk keperluan diet (Herawaty \& Moulina, 2015). Produk nata banyak digunakan sebagai pencampur es krim, es buah, sirup dan sebagainya (Syamsu, dkk., 2015).

Nata de coco dibuat dengan memanfaatkan substrat seperti air kelapa, namun selain dari air kelapa nata juga dapat dibuat dari sumber biomassa lainnya untuk difermentasikan secara aerob dengan bantuan mikroba (Hamad, dkk., 2015). Pemberian nama jenis nata diawali dengan kata nata dan diikuti nama jenis bahan baku yang digunakan dibelakang kata nata.[6] Sebagai contoh nata de 
cassava dari ampas basah tapioca (Mayasti \& Nugroho, 2013), nata de pina dari sari nanas, nata de mango dari buah mangga (Saputra \& Hidaiyanti, 2015), nata de banana peel dari kulit pisang (Wahyudi, 2013), nata de citrus dari jeruk asam (Ratnawati, 2007), Nata de leri dari limbah air cucian beras (Wahab, dkk., 2016), Nata de chayote dari buah labu siam (Kurniawan, dkk., 2014) dan sebagainya. Pada prinsipnya medium nata adalah cairan yang mengandung gula dan vitamin serta mineral(Pilliangsani, 2012).

Selain di atas, nata juga dapat dibuat dari bahan lain yaitu dari ekstrak jagung. Jagung tak hanya kaya vitamin $C$ dan asam folat (Dalimartha, 2011). Biji jagung sebagai sumber karbohidrat mempunyai kandungan pati sekitar 65,50\%, kandungan lemak dalam biji jagung berkisar antara 5,01\%8,56\%, tergantung varietasnya (Rahayu \& Djafar, 2001). Selain sebagai sumber karbohidrat jagung juga mengandung protein yang cukup tinggi. Kandungan protein biji jagung berkisar antara 8,29\% - 10,25\% tergantung varietasnya. Biji jagung mengandung serat kasar berkisar antara 4,12\% - 5,75\%. Serat tidak memiliki nilai gizi yang berarti bagi tubuh kita, namun serat berfungsi dalam memperlancar fungsi pencernaan. Sebagian besar kandungan serat biji jagung terdapat pada kulit biji.

Dari uraian latar belakang diatas maka peneliti melakukan penelitian tentang pengaruh variasi konsentrasi jagung terhadap kualitas nata de corn. 


\section{METODE PENELITIAN}

\section{BAHAN DAN ALAT}

Bahan yang digunakan dalam penelitian ini adalah biji jagung, starter nata (Acetobacter xylinum), kecambah, gula pasir, asam asetat glacial dan air.

Alat yang digunakan adalah neraca timbang, panci, kompor, gelas ukur, pisau, gunting, sendok makan, desikator, saringan, pengaduk sayur, kertas label, jangka sorong, pengaduk, kertas koran, solatif, karet, aluminium foil, kertas saring, oven dan wadah pencetak nata.

\section{PROSEDUR}

Biji jagung yang sudah kering kemudian ditimbang dengan konsentrasi 0\%, 10\%, 20\%, dan 30\% selanjutnya dibersihkan dari pengotornya, setelah bersih dimasukkan kedalam panci dan dimasak sampai mendidih lalu didinginkan, setelah itu substrat disaring menggunakan saringan. Kemudian substrat ditambahkan gula 100 gram dan asam asetat $1 \mathrm{ml}$ dan ekstrak kecambah 7,5 ml. Lalu substrat dipanaskan hingga mendidih sambil diaduk. Setelah itu ditutup dan didinginkan sampai suhu kamar. Substrat diinokulasi dengan stater Acetobacter xylinum sebanyak 10 $\mathrm{ml}$ kemudian substrat difermentasikan selama 13 hari dalam ruangan tertutup pada suhu kamar. Setelah 13 hari, lapisan putih yang terbentuk dari proses fermentasi diambil dari wadah inkubasi. Untuk membersihkan nata dari lendir, permukaan lapisan nata dikeruk menggunakan sendok 
makan. Kemudian nata dicuci dengan air mengalir. Nata yang sudah dibersihkan siap untuk dianalisa (Effendi, 2009).

\section{HASIL DAN PEMBAHASAN}

\section{HASIL PENELITIAN}

Penelitian ini dilakukan di Laboratorium Tadris Kimia UIN Mataram. Kacang-kacangan merupakan sumber nitrogen dan protein yang baik untuk kandungan berkisaran 20-35\%. Salah satu golongan kacang-kacangan adalah kecambah yang diduga dapat menggantikan peran ZA atau urea sebagai sumber nitrogen dalam pembuatana nata. Adapun nata yang berjamur disebabkan karena nata yang tipis mempunyai struktur yang lebih rapat dengan kandungan air yang lebih rendah sehingga cepat mengalami jamuaran. Adapun hasilnya antara lain:

1. Berdasarkan Parameter Rendemen

Berikut diagram batang rerata tinggi rendemen nata

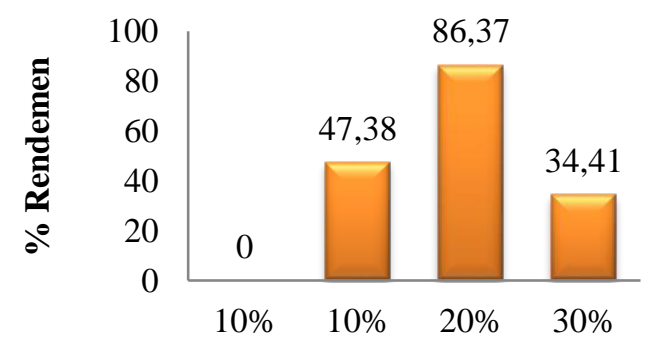

Konsentrasi Jagung

Gambar 4.1 Diagram Batang Hasil Tinggi Rendemen 
Gambar 4.1 di atas menunjukkan rerata rendemen nata setelah ditimbang. Rerata tertinggi ditunjukkan pada perlakuan ke rerata terbanyak ditunjukkan pada perlakuan ke tiga dengan besar $86,37 \%$, dilanjutkan dengan perlakuan kedua dengan besar 47,38\%, kemudian perlakuan keempat dengan besar 34,41\%, dan rerata terkecil ditunjukan pada perlakuan pertama dengan berat $0 \%$.

2. Berdasarkan Parameter Ketebalan Nata De Corn Berikut diagram batang tinggi ketebalan nata

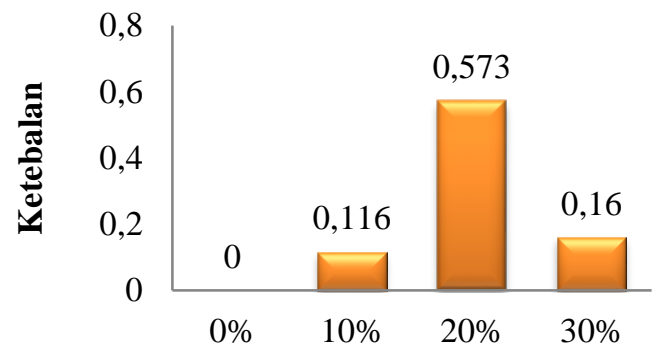

\section{Konsentrasi Jagung}

\section{Gambar 4.2 Diagram Batang Hasil Tinggi Ketebalan}

Gambar 4.2 di atas menunjukkan rerata ketebalan nata de corn. Rerata terbanyak ditunjukkan pada perlakuan ke tiga dengan ketebalan 0,573 cm, dilanjutkan dengan perlakuan ke emapat dengan ketebalan 0,160 cm, kemudian perlakuan kedua dengan ketebalan 0,116 cm, dan rerata terkecil ditunjukkan pada perlakuan ke satu dengan ketebalan $0 \mathrm{~cm}$. 
3. Berdasarkan parameter kadar air

Berikut diagram batang tinggi kadar air nata

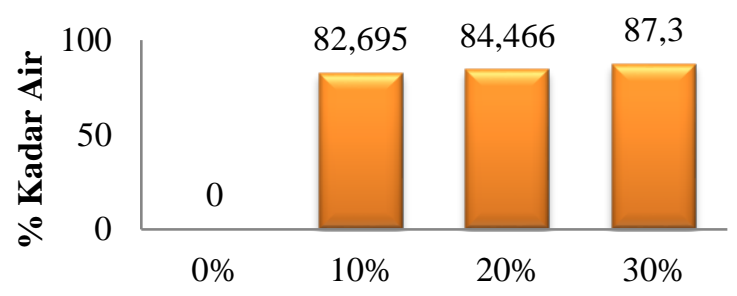

Konsentrasi Jagung

\section{Gambar 4.3 Diagram Batang Hasil Tinggi Kadar air}

Gambar 4.3 di atas menunjukkan rerata jumlah kadar air nata de corn setelah dioven dan didesikator. Rerata terbanyak ditunjukkan pada perlakuan ke empat sebanyak $87,3 \%$, kemudian pada perlakuan ke tiga $84,466 \%$, selanjutnya pada perlakuan ke dua sebanyak 82,695\%, dan kemudian rerata terkecil ditunjukkan pada perlakuan pertama dengan berat o gram.

\section{Tabel 4.4 Rekapitulasi Hasil Akhir Data Untuk 3 Parameter}

\begin{tabular}{|c|r|r|r|}
\hline \multirow{2}{*}{ Perlakuan } & \multicolumn{3}{|c|}{ Parameter } \\
\cline { 2 - 4 } & Rendemen & \multicolumn{1}{c|}{ Ketebalan } & \multicolumn{1}{c|}{ Kadar air } \\
\hline $0 \%$ & 0 & 0 & 0 \\
\hline $10 \%$ & 47,38 & 0,116 & 82,695 \\
\hline $20 \%$ & 86,37 & 0,594 & 84,466 \\
\hline $30 \%$ & 34,41 & 0,160 & 87,3 \\
\hline BNT 5\% & 0,66299 & 0,029 & 0,336 \\
\hline
\end{tabular}

Ket: Angka-angka pada kolom yang sama yang diikuti oleh huruf yang sama pada taraf nyata uji BNT 5\%. 


\section{PEMBAHASAN}

Proses fermentasi pembuatan nata de corn selama 13 hari. Pembentukan nata dengan lama fermentasi menunjukkan bahwa keberhasilan ditandai adanya lapisan putih pada permukaan cairan. Aktivitas pembuatan nata hanya terjadi pada kisaran $\mathrm{pH}$ 3,5 dengan $\mathrm{pH}$ optimum untuk pembentukan nata adalah 4. Suhu yang memungkinkan untuk pembentukan nata adalah pada suhu kamar antara 28$30^{\circ} \mathrm{C}$ dengan bantuan bakteri Acetobacter xylinum.

Acetobacter xylinum memerlukan waktu untuk fase adaptasi selama 1 hari, kemuadian pertumbuhan meningkat untuk hari-hari selanjutnya (Aminatul, 2010). Pengamatan kualitas Nata de corn dilakukan pada tanggal 12 mei 2019, adapun yang diamati pada 12 mei 2019 yaitu rendemen dan ketebalan. Sedangkan untuk hasi kadar air diamati pada tanggal 13 mei 2019. Adapun pengaruh konsentrasi jagung terhadap kualitas nata de corn dapat dijelaskan sebagai berikut:

Data hasil penelitian yang telah dilakukan pada konsentraso $0 \%$ tidak terbentuk nata dikarenakan selain karbon dan nitrogen, pembuatan nata memerlukan vitamin dan mineral yang dalam penelitian ini didapatkan dari jagung, sehingga pembuatan nata dengan konsentrasi $0 \%$ tidak dapat terbentuk sesdangkan pada konsentrasi 30\% kecenderungan bahwa nata yang tipis mempunyai struktur yang lebih rapat dengan kandungan air yang lebih rendah sehingga cepat mengalami jamuaran pada nata yang terbentuk. 
Data hasil penelitian yang telah dilakukan pada tinggi rendemen nata berpengaruh nyata terhadap kualitas nata de corn hal ini dapat dilihat dari data hasil pengamatan rerata tinggi rendemen nata pada Tabel 4.1 rerata tinggi rendemen nata terbesar dapat dilihat dari perlakuan ketiga yaitu dengan rerata $86,37 \%$, sedangkan rerata tinggi rendemen terkecil pada perlakuan pertama dengan rerata tinggi $0 \%$.

Berdasarkan hasil analisis data pada berat nata terendah dikarenakan kandungan sukrosa pada gula dan wadah media substrat cair yang kurang luas, sehingga menyebabkan terhambatnya metabolisme bakteri Acetobacter xylinum sehingga lapisan natapun sulit terbentuk. Ada beberapa faktor yang mempengaruhi terbentuknya rendemen pada nata de corn yaitu waktu fermentasi, ketebalan nata dan ketersediaan oksigen dalam medium. Semakin lama waktu fermentasi yang dilakukan maka nilai rendemen yang diperoleh semakin tinggi. Semakin tebal nata maka rendemennya juga semakin tinggi dan ketersediaan oksigen dalam medium lebih banyak dibandingkan dengan penambahan konsentrasi lain, karena oksigen sangat dibutuhkan oleh Acetobacter xylinum dalam proses metabolisme dan pembentukan partikel nata (Lubis \& Harahap, 2018).

Data hasil pengamatan pada rerata tingggi ketebalan nata terlihat bahwa ketebalan tertinggi yakni pada perlakuan ketiga sebesar $0,573 \mathrm{~cm}$, dan yang paling rendah pada perlakuan pertama sebesar $0 \mathrm{~cm}$ atau nata tidak terbentuk. Hasil analisis data pada pengamatan menunjukkan bahwa perlakuan pertama, kedua, ketiga dan keempat terdapat 
beda nyata. Semakin tinggi kadar karbohidrat, maka nata yang akan terbentuk akan semakin tebal pula. Hal tersebut disebabkan lama fermentasi yang digunakan akan membuat Acetobacter xylinum memproduksi benang-benang selulosa untuk pembentukan nata sehingga nata yang terbentuk akan semakin tebal. Hai ini diperkuat dengan pernyataan Thimann dalam Iryandi, dkk (2018) Acetobacter xylinum mampu mengubah 19\% sukrosa dalam media menjadi selulosa berupa benang yang bersama polisakarida berlendir membentuk jaringan yang secara terus-menerus menjadi nata selama fermentasi berlangsung. Jika konsentrasi sukrosa tinggi maka. Ketebalan yang dihasilkan semakin menurun sehingga nilai rendemennya juga menurun. Penggunaan konsentrasi starter $A$. xylinum yang dianjurkan dalam pembuatan nata tidak lebih dari 15\%. Jika jumlah starter yang diberikan melebihi 15\% dari volume media fermentasi maka bakteri $A$. xylinum akan kekurangan nutrisi yang diperlukan dalam pembentukan nata. Hal ini akan menghambat proses fermentasi dan dinilai tidak ekonomis, karena bakteri merupakan faktor utama yang berperan penting didalam proses pembentukan nata.

Data hasil pengamatan pada rerata berat kadar air dapat terlihat bahwa berat tertinggi yakni pada perlakuan ke empat $87,3 \mathrm{~cm}$, sedangkan kadar air yang paling rendah ditunjukkan pada perlakuan pertama sebanyak 0\%. Hasil analisis data pada pengamatan menunjukkan bahwa perlakuan pertama, kedua, ketiga dan keempat terdapat beda nyata. Hal ini disebabkan adanya kecenderungan bahwa nata yang tipis mempunyai struktur yang lebih rapat 
dengan kandungan air yang lebih rendah dibandingkan nata yang tebal, sehingga kadar air pada nata yang tipis lebih rendah. Demikian sebaliknya nata yang tebal mempunyai struktur selulosa yang lebih longgar dengan kandungan air lebih tinggi. Kadar air tinggi akan diikuti dengan nata de corn yang mempunyai kekenyalan menurun dan kenaikan ketebalan serta kadar serat kasar yang tinggi (Putranto \& Taofik, 2017).

Faktor yang berpengaruh pada pembuatan nata yaitu Jaringan selulosa bakterial yang terbentuk lembaran yang mengapung di permukaan medianya telah terbukti mempunyai daya regang, elastisitas, kekenyalan, daya tahan, ketahanan bentuk, dan kapasitas serap air yang tinggi (Seto \& Sari, 2013). Adapun faktor pendukung lain yang mempengaruhi produksi nata adalah nutrisi, aktivitas bakteri Acetobacter xylinum, jenis bibit, umur bakteri, konsentrasi sukrosa, sumber nitrogen, dan lama fermentasi.

Faktor nutrisi mempunyai pengaruh yang kuat tehadap terhadap sifat, hasil dan komposisi selulosa yang terbentuk. Kecukupan konsentrasi sumber karbon dalam medium dapat merangsang mikroorganisme dalam mensintesa selulosa dan menghasilkan nata dengan ikatan selulosa yang kuat.Kuatnya ikatan selulosa dalam jaringan nata tersebut mengakibatkan serat nata, berat, dan ketebalannya juga semakin tinggi atau meningkat (Kusmiati, 2018).

Nitrogen merupakan salah satu unsur yang dapat merangsang pertumbuhan dan aktivitas bakteri Acetobacter xylinum. Nitrogen dapat berasal dari sumber nitrogen 
organik maupun anorganik, misalnya ekstrak khamir, pepton, amonium sulfat, kalium nitrat dan amonium fosfat. Sampai saat ini sumber nitrogen yang biasa digunakan dalam pengolahan nata de coco adalah amonium sulfat (ZA) karena mudah diperoleh dan relatif murah, akan tetapi pengolahan nata de corn menggunakan ekstrak kecambah sebagai pengganti ammonium sulfat (ZA) sebagai sumber nitrogen.

Penambahan sukrosa merupakan salah satu faktor penting dalam pembuatan nata. Tanpa penambahan sukrosa ke dalam medium fermentasi, lapisan nata tidak dapat terbentuk. Faktor-faktor inilah yang harus diperhatikan untuk memperoleh nata de corn yang berkualiatas baik. Disamping itu, dalam pembuatannya sangat memerlukan ketelitian dan sterilitas alat dan penggunaan bahan yang tepat.

Keberhasilan proses fermentasi nata pada baki fermentasi sangat dipengaruhi oleh starter (mother liquor) yang digunakan sebagai bibit. Pertumbuhan populasi bakteri Acetobacter xylinum dalam botol inkubasi dapat optimal apabila media yang digunakan betul-betul septik dan unsur nutrien yang dibutuhkan untuk pertumbuhan bakteri tersebut tersedia. Dalam penelitian ini aktivitas Acetobacter xylinum secara visual terlihat maksimal pada hari ke sembilan, dimana pada saat itu pembentukan lapisan nata di atas permukaan larutan dalam botol berlangsung cepat. Sehingga penggunaan starter sebagai bibit dalam penelitian ini yaitu pada saat starter berumur 9 hari.Sementara larutan utama yang difermentasi dalam baki fermentasi juga dapat dipanen seluruhnya pada umur sembilan hari. Jika nata 
sudah terbentuk dengan sempurna, namun terlambat dipanen, nata akan mengalami detereorasi (terurai kembali) atau terkontaminasi oleh jamur atau bakteri lainnya sehingga mutu nata yang diperoleh rendah.

\section{KESIMPULAN}

Berdasarkan hasil penelitian dan pembahasan, dapat disimpulkan bahwa :

1. konsentrasi jagung berpengaruh nyata terhadap rendemen, ketebalan dan kadar air.

2. konsentrasi yang paling bagus dalam menghasilkan kualitas nata de corn terdapat pada perlakuan ke 3 yaitu konsentrasi $20 \%$.

\section{DAFTAR PUSTAKA}

Aminatul. (2010). Pemanfaatan Nata Decassava Skin Menjadi

Minuman Aneka Rasa Sebagai Upaya Cerdas Menambah Nilai Ekonomis Limbah Singkong pada Masyarakat di Jalan Jombang Malang. (Skripsi). Malang: Universitas Negeri Malang.

Dalimartha, S. \& Adrian, F. (2011). Khasiat Buah Dan Sayur. Penerbit: Penebar Swadaya.

Effendi, N. H. (2009). Pengaruh Penambahan Variasi Massa Pati (Soluble Starch) Pada Pembuatan Nata De Coco Dalam Medium Fermentasi Bakteri Acetobacter Xylinum. (Skripsi). Departemen Kimia Universitas Sumatera Utara. 
Hamad, A., Hidayah, B. I., Solekhah, A., \& Septhe, A. G. (2017). Potensi Kulit Nanas Sebagai Substrat Dalam Pembuatan Nata De Pina. Jurnal Riset Sains dan Teknologi. 1 (1). 9-14

Herawaty, N. \& Moulina, M. A. (2015). Kajian Variasi Konsentrasi Sukrosa Terhadap Karakteristik Nata Timun Suri (Cucumis Sativus L.). Jurnal Agritepa. 1.

Iryandi, A. F., Hendrawa, Y., \& Komar, N. (2014). Pengaruh Penambahan Air Jeruk Nipis (Citrus Aurantifolia) Dan Lama Fermentasi Terhadap Karakteristik Nata De Soya. Jurnal Bioproses Komoditas Tropis. 1 (1). 8-15.

Kurniawan, F., Sulistiyana, Ulfin, I. (2014). New Bacterial Cellulose Membranes from Chayote Fruits dan bamboo shoots. International Journal of Applied Chemistry. 10(2). 101-112.

Kusmiati, E. (2018). Pengaruh Konsentrasi Gula Pasir Terhadap Kualitas Nata De Cassava. (Skripsi). UIN Mataram: Pendidikan Biologi, Fakultas Tarbiyah dan Keguruan.

Lubis, A. W., \& Harahap, D. N. (2018). Pemanfaatan Sari Buah Naga Super Merah (Hylocereus Costaricensis) pada Pembuatan Nata De Coco Terhadap Mutu Fisik Nata. Journal Of Chemistry Education And Science. 2(2). 1-10.

Majesty, J,. Agr, B. D., \& Nugroho, W. A., (2015). Pengaruh Penambahan Sukrosa dan Lama Fermentasi Terhadap Kadar Serat Nata Dari Nanas (Nata De Pina). Jurnal Keteknikan Pertanian Tropis dan Biosistem. 3 (1). 1 -28. 
Mayasti, N. K. I. \& Nugroho, D. A. (2013). Pemanfaatan Ampas Basah Tapioka Sebagai Media Fermentasi Dalam Pembuatan Nata De Cassava. Jurnal Pangan. $22(4) \cdot 365-372$.

Pilliangsani, H. M. (2012). A to Z Sukses Bisnis Rumahan, Jakarta: PT Gramedia.

Putranto, K. \& Taofik, A. (2017). Penambahan Ekstrak Toge Pada Media Nata De Coco. Jurnal edisi. 10 (2).

Rahayu, S., \& Djafar, T. F. (2001). Aneka Macam Olahan Jagung. Yogyakarta: Kanisius.

Ratnawati, D. (2007). Kajian Variasi Kadar Glukosa Dan Derajat Keasaman $(\mathrm{pH})$ pada Pembuatan Nata De Citrus dari Jeruk Asam Citrus Limon. L. Jurnal Gradien. 3(2). $257-261$.

Saputra, F. \& Hidaiyanti, R. (2015). Pengaruh Penggunaan Berbagai Macam Varietas Mangga Terhadap Kualitas Nata De Mango. Jurnal Agritepa. I(2). 128 -135.

Seto, A. S., \& Sari, A. M. (2013). Pembuatan Selulosa Asetat Berbahan Dasar Nata De Soya. Jurnal Konversi. 2 (2). 112.

Syamsu, A. S. I., Firdaus, S., \& Imran, A. (2015). Pembuatan Nata De Rice Dari Air Cucian Beras Dalam Beberapa Konsentrasi Dengan Bakteri Acetobacter Xylinum. Jurnal As-Syifaa. 07.

Wahab, H., Ahmadi., \& Hulyadi. (2016). Perbandingan Volume dan Massa Nutrien Optimum Pada 
Karakteristik Kimia Nata De Leri Dari Limbah Air Cucian Beras. Jurnal Ilmiah Pendidikan Kimia Hydrogen. 4 (1). $26-30$.

Wahyudi. (2013). Pemanfaatan Kulit Pisang (Musa Paradisiaca) Sebagai Bahan Dasar Nata De Banana Peel Dengan Penambahan Gula Aren Dan Gula Pasir. (Skripsi). Fakultas Keguruan Dan Ilmu Pendidikan Universitas Muhammadiyah Surakarta.

Warisno. (2009). Inspirasi Usaha Membuat Aneka Nata. Jakarta: Penerbit PT Agro Media. 